\title{
The role of epigenetic inactivation of 14-3-3 $\sigma$ in human cancer
}

\author{
Dmitri LODYGIN, Heiko HERMEKING* \\ Molecular Oncology, Max-Planck Institute of Biochemistry, Am Klopferspitz 18, Martinsried/Munich, Germany
}

\begin{abstract}
Cancer cells show characteristic alterations in DNA methylation patterns. Aberrant CpG methylation of specific promoters results in inactivation of tumor suppressor genes and therefore plays an important role in carcinogenesis. The p53-regulated gene 14-3-3 $\sigma$ undergoes frequent epigenetic silencing in several types of cancer, including carcinoma of the breast, prostate, and skin, suggesting that the loss of 14-3-3 $\sigma$ expression may be causally involved in tumor progression. Functional studies demonstrated that 14-3-3 $\sigma$ is involved in cell-cycle control and prevents the accumulation of chromosomal damage. The recent identification of novel 14-3-3 $\sigma$-associated proteins by a targeted proteomics approach implies that 14-3-3 $\sigma$ regulates diverse cellular processes, which may become deregulated after silencing of 14-3-3 $\sigma$ expression in cancer cells.
\end{abstract}

Keywords: $14-3-3 \sigma, \mathrm{CpG}$ methylation, p53, epigenetic silencing, cancer, cell cycle.

\section{INTRODUCTION}

In the process of neoplastic transformation changes in the function of critical genes which allow cells to overgrow their neighboring cells are selected for. The altered genes which are causally involved in carcinogenesis can be broadly divided in two major classes: oncogenes and tumor suppressor genes. Whereas oncogenes gain an increased function via activating point mutations or gene amplification, tumor suppressor genes lose their function in cancer cells. Tumor suppressor genes may be subdivided into caretakers and gatekeepers [1]. Caretaker genes encode proteins which function in the preservation of genomic integrity, whereas gatekeepers keep cells in a defined state of differentiation.

The inactivation of tumor suppressor genes is mediated by two mechanisms: genetic inactivation by DNA mutations and epigenetic silencing. In some cases genetic and epigenetic events complement each other (Fig. 1). In general bi-allelic gene inactivation resulting in complete loss of function is characteristic for tumor suppressor genes. This review will focus on the epigenetic inactiva-

*Correspondence: Heiko HERMEKING

Tel: 001-49-(0)-89-8578-2875

Fax: 001-49-(0)-89-8578-2540

E-mail: herme@biochem.mpg.de tion of 14-3-3 $\sigma$ gene expression in human cancers and possible functional implications of the loss of 14-3-3 $\sigma$ function for the progression of tumors.

\section{EPIGENETIC SILENCING IN CANCER}

The term epigenetic refers to information which is transmitted from the parental genome to the next generation of cells which is not encoded by the primary DNA sequence. Epigenetic mechanisms are essential for the regulation of gene expression and genome integrity in normal cells (for reviews see [2-4]). Epigenetic information is often transmitted by methylation of the 5 carbon position of cytosine within a $\mathrm{CpG}$ dinucleotide, also referred to as DNA methylation. $\mathrm{CpG}$ dinucleotides are under-represented in the genome, but over-represented in short regions of 5004,000 bp (base pair) in length, known as CpG islands, which are rich in $\mathrm{CpG}$ content $[3,5]$. CpG islands are present in the proximal promoter regions of about $60 \%$ of the genes in the mammalian genome and are, generally, unmethylated in normal cells.

Patterns of DNA methylation and chromatin structure are profoundly altered in neoplasia and include genomewide losses of and regional gains in DNA methylation [6]. Global hypomethylation was shown to cause genomic instability which in turn may promote secondary genetic alterations $[7,8]$, whereas local hypermethylation of promoter regions is associated with transcriptional silencing 


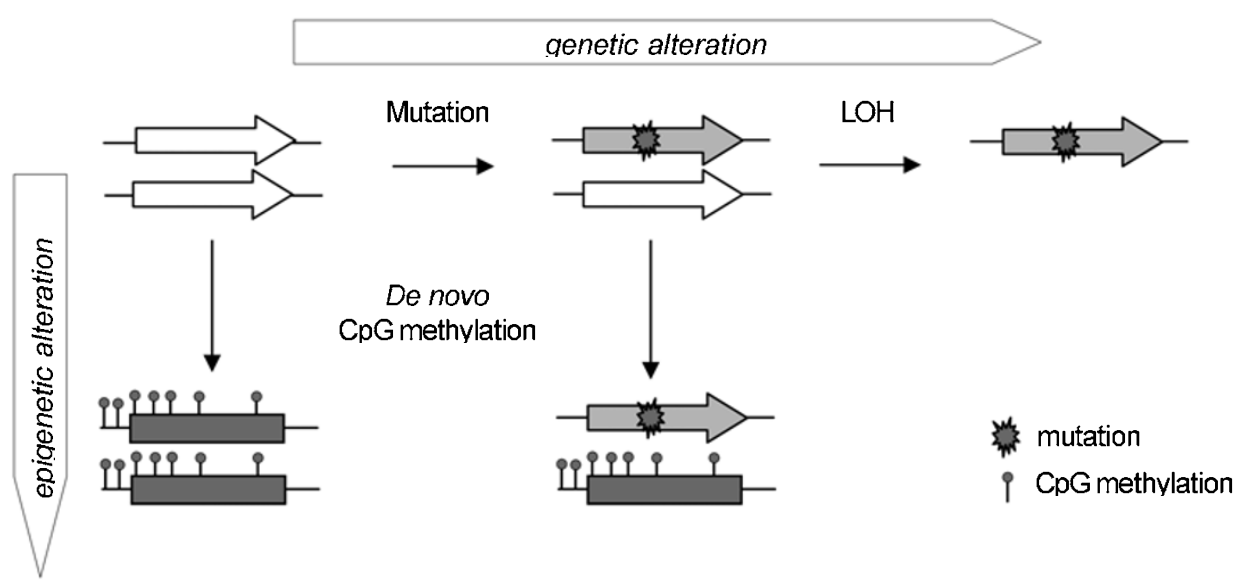

Fig. 1 Mechanisms of tumor suppressor gene inactivation in cancer. In diploid cells one allele of a tumor suppressor gene can be inactivated by a point mutation. The remaining allele is frequently lost due to deletion of the gene, also designated as loss of heterozygosity (LOH). Alternatively, the second allele can undergo de novo methylation and therefore become transcriptionally silent. It is also possible, that both alleles are silenced by aberrant promoter methylation.

and can lead to the loss of tumor-suppressor gene function. The molecular mechanisms of epigenetic silencing during tumor formation are only partially understood. In normal cells the pattern of $\mathrm{CpG}$ methylation is established by two types of methyltransferases catalyzing the addition of a methyl-group at the C-5 position of cytosine: DNMT1 serves as a maintenance methyltransferase, whereas DNMT3A and DNMT3B mediate de novo DNA methylation. All three DNMTs are modestly over-expressed at the mRNA and/or protein level in many types of tumor cells $[9,10]$. Ectopic expression of DNMT1 cooperates with oncogenes in the transformation of primary cells supporting the idea that aberrant expression of DNA methyltransferases may contribute to abnormal promoter methylation in cancer cells [11] .

Factors directing the activity of DNMTs to specific genomic sites under normal and pathological conditions remained largely unknown. Covalent modifications of core histones may serve as plausible marks for the establishment of DNA methylation. The methylation of histone H3 lysine 9 was shown to be a prerequisite for DNA methylation in Neurospora crassa and Arabidopsis thaliana [12, 13]. Although this requirement does not seem to be conserved in mammalian cells, the concept that histone methylation provides a signal which somehow can be interpreted by DNA methylation machinery is supported by experimental data. For example, the histone methyltransferase Suv39H1 directs DNA methylation to satellite repeats at pericentric heterochromatin [14]. The $p 16^{I N K 4 A}$ gene has been shown to undergo re-activation after reversal of DNA methylation after experimental removal of
$D N M T$ activity in colorectal cancer cells [15]. Subsequent re-silencing of $p 16^{I N K 4 A}$ occurred after prolonged passage of these cells. Methylation of histone H3-K9 was detected in association with re-silencing of this tumor suppressor gene in the absence of DNA methylation [15]. Therefore, the methylation of histones may precede methylation of DNA during epigenetic silencing of tumor suppressor genes. In plants and some animals double stranded RNAs were implicated in the guidance of de novo methylation [16, 17]. Also, RNAi-mediated transcriptional silencing has been associated with promoter methylation in human cells [18, 19]. In addition, transcription factors which interact with DNA in a sequence-specific manner may direct CpG methylation to specific promoters. In line with this hypothesis, it was recently shown that the Myc protein recruits DNMT3A methyltransferase to the $p 21^{\text {WAFI }}$ promoter and represses its expression through $\mathrm{CpG}$ methylation [20]. However, so far it is unclear whether any of these mechanisms plays a role in establishing the aberrant methylation patterns seen in human malignancies.

Methylated CpG-dinucleotides are bound by the methylCpG-binding domain (MBD) containing proteins MBD1, MBD2, MBD3, MBD4 and MeCP2. The protein Kaiso binds to methylated $\mathrm{CpG}$ groups via its zinc-finger motif. With the exception of MBD4, which operates in mismatch repair, these proteins were shown to recruit chromatin remodeling factors (e.g. the Mi2/NuRD complex) and histone deacetylases (HDAC) to the respective promoters and thereby establish transcriptionally inactive chromatin (Fig. 2). How and at which stage of tumor progression $\mathrm{CpG}$ methylation of tumor suppressive genes is established 

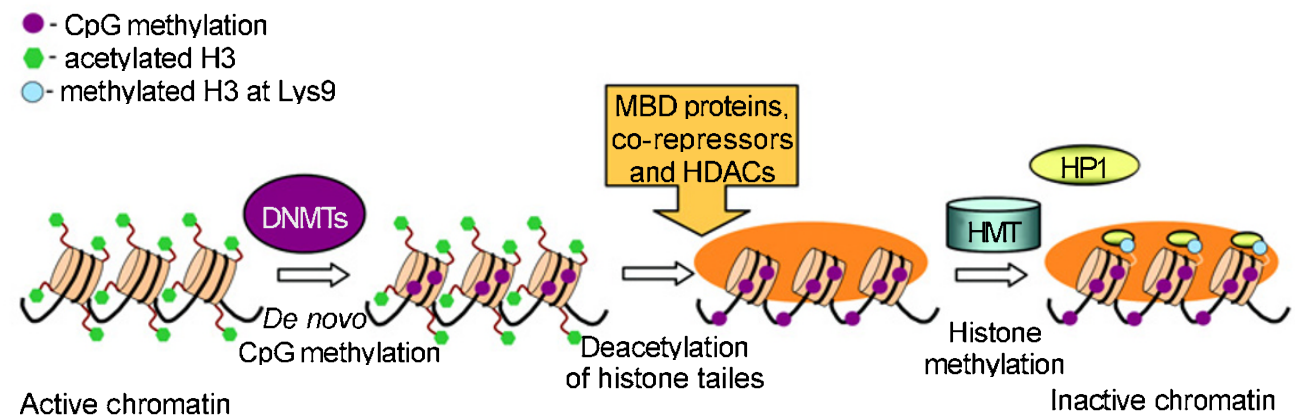

Fig. 2 The relationship between DNA methylation and chromatin structure. The carbon atom at the 5' position of cytosines within a CpGdinucleotide context can be methylated by DNA methyltransferases (DNMTs). Clusters of methylated CpGs are recognized and bound by specific proteins sharing a methyl-CpG binding domain (MBD). In turn, MBD proteins recruit transcriptional co-repressors, chromatin remodeling complexes and histone deacetylases (HDACs). Deacetylation of histone tails (N-terminal parts of histone H3 and H4) results in alteration of nucleosomal structure and decrease in transcriptional activity of the chromatin. Subsequent methylation of histone tails by histone methyltransferases (HMTs) (particularly, lysine 9 of H3 and lysine 20 of H4) and recruitment of auxiliary proteins, such as heterochromatin binding protein 1 (HP1), enhance the formation of transcriptionally incompetent heterochromatin.

is unknown. Stochastic, age-associated accumulation of aberrantly methylated CpG-sites may be involved in this process.

Epigenetic inactivation of tumor suppressor genes significantly contributes to tumor development [21]. The genes aberrantly methylated in human cancers fall into functional categories intimately involved in cellular processes relevant to carcinogenesis such as DNA repair (MGMT, MLH1, BRCA1), cell cycle control (CDK inhibitors, $p 15, p 16, p 27)$, apoptosis (APAF1, CASP8), invasion (CDH1, TIMP3) and angiogenesis (THBS1, VHL). Nearly $50 \%$ of the genes that cause familial forms of cancer when mutated in the germ line are known to undergo methylation-associated silencing in various sporadic forms of cancer [21]. Although some methylation changes seem to be common to many kinds of cancer, tissue-specific differences exist. For example, the $p 15^{I N K 4 B}$ promoter is frequently methylated in lymphoid, but not in solid cancers [22], and glutathione S-transferase p 1 (GSTP1) is methylated in prostate, breast and hepatic cancers, but rarely in others [23].

Experimental reversion of DNA methylation leads to re-expression of silenced genes in tumor cells, which may have consequences at the cellular level: e.g. restored sensitivity to apoptotic stimuli after reactivation of caspase 8 [24] or inhibition of cell-proliferation after re-expression of the CDK-inhibitor $p 16$ [25]. Consistent with a role of hypermethylation-mediated gene repression in tumor formation, inactivation of $D N M T 1$ or $M B D 2$ suppresses intestinal tumorigenesis in $A p c^{\text {min }}$ mice [26, 27].

Although $\mathrm{CpG}$ methylation patterns can be erased during DNA replication in the absence of DNMT activity, aberrant epigenetic marks persist through multiple generations of cells and are as stable as genetic alterations. For example most cancer cell lines maintain the pattern of aberrant DNA methylation characteristic for primary tumors of the same tissue origin [28]. Moreover, aberrant methylation of CpG-islands, also called epimutation, can be transmitted through the germ line, as recently shown for the MLH1 gene [29].

\section{SILENCING OF 14-3-3 $\sigma$ IN CANCER}

The p53-regulated 14-3-3 $\sigma$ gene displays a number of properties (reviewed in [30] and discussed in the next section), which suggest that this gene may function in tumor suppression. SAGE analysis revealed down-regulation of 14-3-3 $\sigma$ in breast cancer cells [31]. A subsequent search for the mutations in the 14-3-3 $\sigma$ locus did not reveal any genetic alterations which could explain its downregulation. Instead the epigenetic silencing by $\mathrm{CpG}$ methylation turned out to be responsible for the loss or reduction of $14-3-4 \sigma$ expression in more than $90 \%$ of $\sim 90$ analyzed primary breast cancer samples [32]. The treatment of breast cancer cells with an inhibitor of DNA methyltransferases, 5-aza-2'-deoxycytidine (5Aza-2'dC), results in re-activation of 14-3-3 $\sigma$ expression, indicating a causal role for hypermethylation in the loss of 14-3-3 $\sigma$ expression [32]. This study provided the first example for loss of 14-3-3 $\sigma$ expression by epigenetic silencing in primary tumors. Subsequently, numerous reports documented silencing of 14-3-3 $\sigma$ gene associated with CpG methylation in several common human malignancies, with a particularly high prevalence in prostate, breast and clear cell type ovarian carcinomas (summarized in the Tab. 1). In 
Tab. 1 Silencing of 14-3-3 $\sigma$ in different types of epithelial tumors

\begin{tabular}{|c|c|c|c|}
\hline Organ & Frequency of $\mathrm{CpG}$ methylation & Expression & Ref. \\
\hline \multirow[t]{4}{*}{$\begin{array}{l}\text { Mammary } \\
\text { gland }\end{array}$} & $\begin{array}{l}86 \%(43 / 50) \text { primary tumors } \\
100 \%(32 / 32) \text { microdissected carcinoma }\end{array}$ & mRNA down-regulation in $96 \%(43 / 45)$ primary tumors & [32] \\
\hline & $\begin{array}{l}96 \%(24 / 25) \text { invasive ductal carcinoma } \\
83 \%(15 / 18) \text { ductal carcinoma in situ } \\
38 \%(3 / 8) \text { atypical hyperplasia }\end{array}$ & ND & [37] \\
\hline & ND & $\begin{array}{l}\text { Protein down-regulation in } \\
77 \%(55 / 71) \text { invasive ductal carcinoma } \\
35 \%(12 / 34) \text { ductal carcinoma in situ } \\
8 \%(24 / 26) \text { usual ductal hyperplasia }\end{array}$ & [51] \\
\hline & ND & $\begin{array}{l}\text { Protein down-regulation in } \\
77 \%(33 / 43) \text { primary breast carcinoma }\end{array}$ & [45] \\
\hline Stomach & $43 \%(26 / 60)$ primary gastric cancer & mRNA down-regulation in cell lines positive for the methylation & [52] \\
\hline \multirow[t]{2}{*}{ Liver } & $89 \%(17 / 19)$ primary HCC & Protein down-regulation in $88 \%(14 / 16)$ primary $\mathrm{HCC}$ & [39] \\
\hline & $\begin{array}{l}60 \%(47 / 79) \text { intrahepatic } \\
\text { cholangiocarcinoma }\end{array}$ & ND & [53] \\
\hline \multirow[t]{2}{*}{ Lung } & $\begin{array}{l}33 \%(/ 24) \text { microdissected primary SCLC } \\
69 \%(9 / 13) \text { SCLC cell lines } \\
57 \%(4 / 7) \text { large-cell NSCLC cell lines } \\
6 \%(1 / 17) \text { other NSCLC cell lines }\end{array}$ & $\begin{array}{l}\text { Protein down-regulation in } \\
100 \%(8 / 8) \text { primary SCLC } \\
5 \%(1 / 22) \text { primary NSCLC }\end{array}$ & [54] \\
\hline & ND & $\begin{array}{l}\text { Protein down-regulation in } \\
86 \%(23 / 28) \text { neuroendocrine tumors including typical }(5 / 5) \text { and } \\
\text { atypical }(2 / 2) \text { carcinoids, large cell neuroendocrine carcinoma }(6 / 7) \\
\text { and SCLC }(15 / 18) 1 \%(1 / 74) \text { NSCLC }\end{array}$ & [55] \\
\hline Skin & $\begin{array}{l}68 \%(28 / 41) \text { microdissected primary basal } \\
\text { cell carcinoma }\end{array}$ & $\begin{array}{l}\text { Protein down-regulation in } \\
71 \%(29 / 41) \text { basal cell carcinoma }\end{array}$ & [38] \\
\hline \multirow{4}{*}{$\begin{array}{l}\text { Squamous } \\
\text { epithelia of } \\
\text { the mucous } \\
\text { surfaces }\end{array}$} & $\begin{array}{l}35 \%(32 / 92) \text { primary oral SSC } \\
50 \%(3 / 6) \text { oral displasia }\end{array}$ & $\begin{array}{l}\text { mRNA down-regulation in } 100 \%(32 / 32) \text { methylation-positive SCC } \\
\text { Protein down-regulation in all methylation-positive SCC }(n=36)\end{array}$ & [46] \\
\hline & $\begin{array}{l}56 \%(20 / 36) \text { vulval SCC } \\
47 \%(15 / 32) \text { VIN }\end{array}$ & mRNA down-regulation in $72 \%(26 / 36)$ vulval SCC & [56] \\
\hline & ND & $\begin{array}{l}\text { Protein down-regulation in } \\
18 \%(5 / 27) \text { cervical adenocarcinoma } \\
13 \%(2 / 15) \text { cervical adenosquamous carcinoma }\end{array}$ & [44] \\
\hline & ND & $\begin{array}{l}\text { Protein down-regulation in } \\
33 \%(3 / 9) \text { primary cervical carcinoma }\end{array}$ & [45] \\
\hline Endometrium & $\begin{array}{l}\text { Methylation associated with IHC-nega- } \\
\text { tivity (primary adenocarcinoma } n=19 \text { ) }\end{array}$ & $\begin{array}{l}\text { Protein down-regulation in } \\
43 \%(20 / 46) \text { primary adenocarcinoma }\end{array}$ & [45] \\
\hline \multirow[t]{3}{*}{ Ovary } & $\begin{array}{l}79 \%(11 / 14) \text { clear cell adenocarcinoma } \\
26 \%(5 / 19) \text { serous adenocarcinoma } \\
36 \%(4 / 11) \text { mucinous adenocarcinoma } \\
20 \%(2 / 10) \text { endometrioid adenocarcinoma }\end{array}$ & $\begin{array}{l}\text { Protein down-regulation in } \\
79 \%(11 / 14) \text { clear cell type } \\
10 \%(2 / 19) \text { serous type } \\
18 \%(2 / 11) \text { mucinous type } \\
10 \%(1 / 10) \text { endometrioid type of adenocarcinoma }\end{array}$ & [35] \\
\hline & $\begin{array}{l}58 \%(7 / 12) \text { ovarian cancer cell lines } \\
30 \%(3 / 10) \text { IHC-positive } \\
80 \%(8 / 10) \text { IHC-negative } \\
\text { microdissected adenocarcinoma }\end{array}$ & $\begin{array}{l}\text { mRNA down-regulation in } \\
58 \%(7 / 12) \text { ovarian cancer cell lines } \\
\text { Protein down-regulation in } \\
26 \%(27 / 102) \text { primary adenocarcinoma }\end{array}$ & [57] \\
\hline & $\begin{array}{l}\text { Methylation associated with IHC-negativ- } \\
\text { ity (primary adenocarcinoma } n=17 \text { ) }\end{array}$ & Protein down-regulation in $67 \%(14 / 21)$ primary adenocarcinoma & [45] \\
\hline \multirow[t]{4}{*}{ Prostate } & ND & $\begin{array}{l}\text { Protein down-regulation in } 90 \%(n=111) \text { primary carcinoma and } \\
\text { PIN }\end{array}$ & [58] \\
\hline & $\begin{array}{l}100 \%(41 / 41) \text { microdissected primary } \\
\text { prostate adenocarcinoma }\end{array}$ & $\begin{array}{l}\text { Protein down-regulation in } 63 \%(26 / 41) \text { primary carcinoma and } \\
\text { PIN }\end{array}$ & [33] \\
\hline & $\begin{array}{l}\text { Methylation associated with IHC-nega- } \\
\text { tivity (primary adenocarcinoma } n=30 \text { ) }\end{array}$ & Protein down-regulation in $45 \%(18 / 40)$ primary carcinoma & [45] \\
\hline & $33 \%(1 / 3)$ prostate carcinoma cell lines & Protein down-regulation in $94 \%(72 / 76)$ primary carcinoma & [59] \\
\hline
\end{tabular}

$\mathrm{HCC}=$ hepatocellular carcinoma; IHC = immunohistochemistry; $n=$ number of analyzed cases; ND = not determined; NSCLC = nonsmall cell lung cancer; PIN = prostate intraepithelial hyperplasia; SCLC = small cell lung cancer; SSC = squamous cell carcinoma; VIN = vulval intraepithelial hyperplasia. 


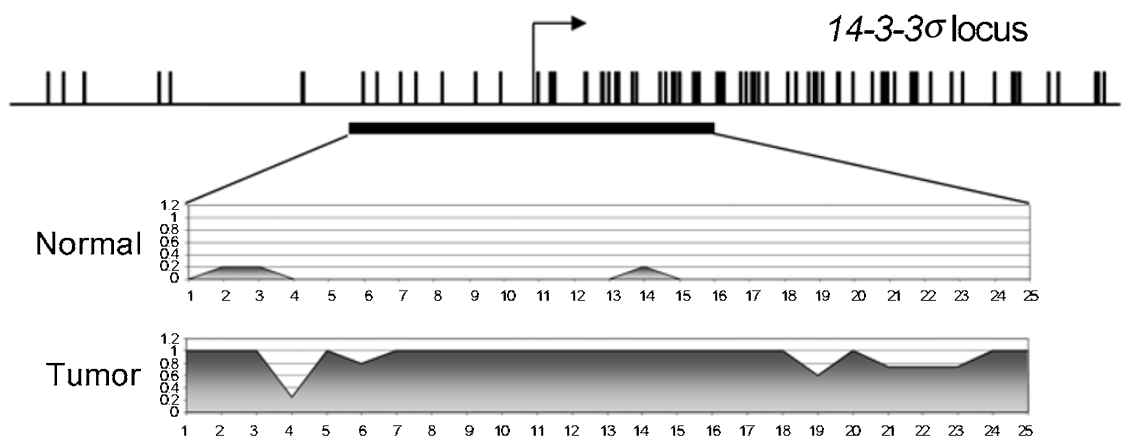

Fig. 3 The pattern of CpG methylation in promoter region of 14-3-3 $\sigma$ in primary prostate epithelial cells ("Normal") and the prostate cancer cell line LNCaP ("Tumor"). The depicted areas correspond to $2.5 \mathrm{~kb}$ genomic DNA sequences. Vertical bars represent CpG-dinucleotides. The position of the transcription start site is indicated by an arrow. The black bar indicates the region studied by bisulfite sequencing. Grey shaded chart areas represent frequencies of methylated $\mathrm{CpGs}$. The $y$-axis corresponds to the relative abundance of methylation of the $\mathrm{CpG}-$ dinucleotide at the indicated relative positions.

many cases silencing of $14-3-3 \sigma$ was identified by a candidate approach. We recently identified silencing of $14-3-3 \sigma$ when we applied an unbiased, genome-wide approach to identify genes silenced in prostate cancer cell lines (Fig. 3, $[33,34])$. Alterations in the expression of $14-3-3 \sigma$ were shown to be characteristic for distinct cell types in tumors of the same location. For example, 14-3-3 $\sigma$ expression was used to distinguish various types of ovarian carcinoma [35], and to discriminate between urothelial and prostate carcinoma [36].

In breast cancer progression the frequency of hypermethylation gradually increases upon transition from atypical hyperplasia to invasive breast carcinoma [37] (Tab. 1). Moreover, hypermethylation of 14-3-4 $\sigma$ was detected in adjacent histologically normal breast epithelium, while $\mathrm{CpG}$ methylation in breast epithelial cells was never observed in individuals without evidence of breast cancer. It has been proposed that hypermethylation of $14-3-4 \sigma$ is an early event during breast cancer formation that precedes any morphological change in tissue architecture or cell shape [37]. We made a similar observation in tissues containing basal cell carcinoma (BCC) of the skin [38]. Morphologically benign epidermis, adjacent to BCC, showed the presence of $\mathrm{CpG}$ methylation, whereas the epidermis derived from a distant location was free of 143-3 $\sigma$ methylation. Rare methylation in non-neoplastic cells from cancer patients was also observed in prostate [33] and hepatocellular carcinoma [39]. CpG methylation in normal, tumor-adjacent tissue is not an exclusive feature of the 14-3-3 $\sigma$ gene, since it has also been shown for other genes silenced by $\mathrm{CpG}$ methylation, such as the $p 16^{I N K 4 A}$ [40], RAR- $\beta 2$ [41] and TR- $\beta 1$ [42].

Recently, the expression of $14-3-3 \sigma$ protein in breast carcinoma was analyzed using a proteomic approach complemented by immunohistochemical analysis [43]. In contrast to several previous studies [32, 37, 44, 45], which showed loss of 14-3-3 $\sigma$ expression due to epigenetic silencing in the majority of analyzed samples, Moreira and colleagues could detect the loss of 14-3-3 $\sigma$ protein only in 9 of 105 primary breast carcinomas. This issue should therefore be examined in larger numbers of samples.

An inverse correlation between $p 53$ mutations and loss of 14-3-3 $\sigma$ expression through promoter methylation has been reported for oral SCC [46]. This observation is consistent with a role of p53 as an upstream regulator of the 14-3-3 $\sigma$ gene. However, in $\mathrm{BCC}$ and prostate cancer, mutations of $p 53$ are known to be late events, whereas silencing of 14-3-3 $\sigma$ takes place early in tumor progression, e.g. in PIN lesions of the prostate [33, 38].

Presumably, $\mathrm{CpG}$ methylation is also involved in inactivation of 14-3-3 $\sigma$ expression in non-epithelial cells during normal development. For example, its methylation was detected in stromal [33, 37, 38] and lymphoid cells [47], in which this gene is not expressed. Unexpectedly, a strong methylation of 14-3-3 $\sigma$ can be detected in normal epithelial cells of the pancreatic gland, whereas pancreatic cancers display overexpression of 14-3-3 $\sigma$ associated with promoter hypomethylation [48-50].

\section{FUNCTIONS OF THE 14-3-3 $\sigma$ PROTEIN}

14-3-3 $\sigma$, or stratifin (SFN), belongs to the 14-3-3 family comprising six other members in mammals (designated $\beta$, $\varepsilon, \gamma, \eta, \tau, \zeta)$. 14-3-3 proteins form homo- and heterodimers and bind to protein ligands via a consensus binding motif which has to be phosphorylated on serine/threonine residues. The association with 14-3-3 proteins regulates the associated proteins by cytoplasmic sequestration, mask- 


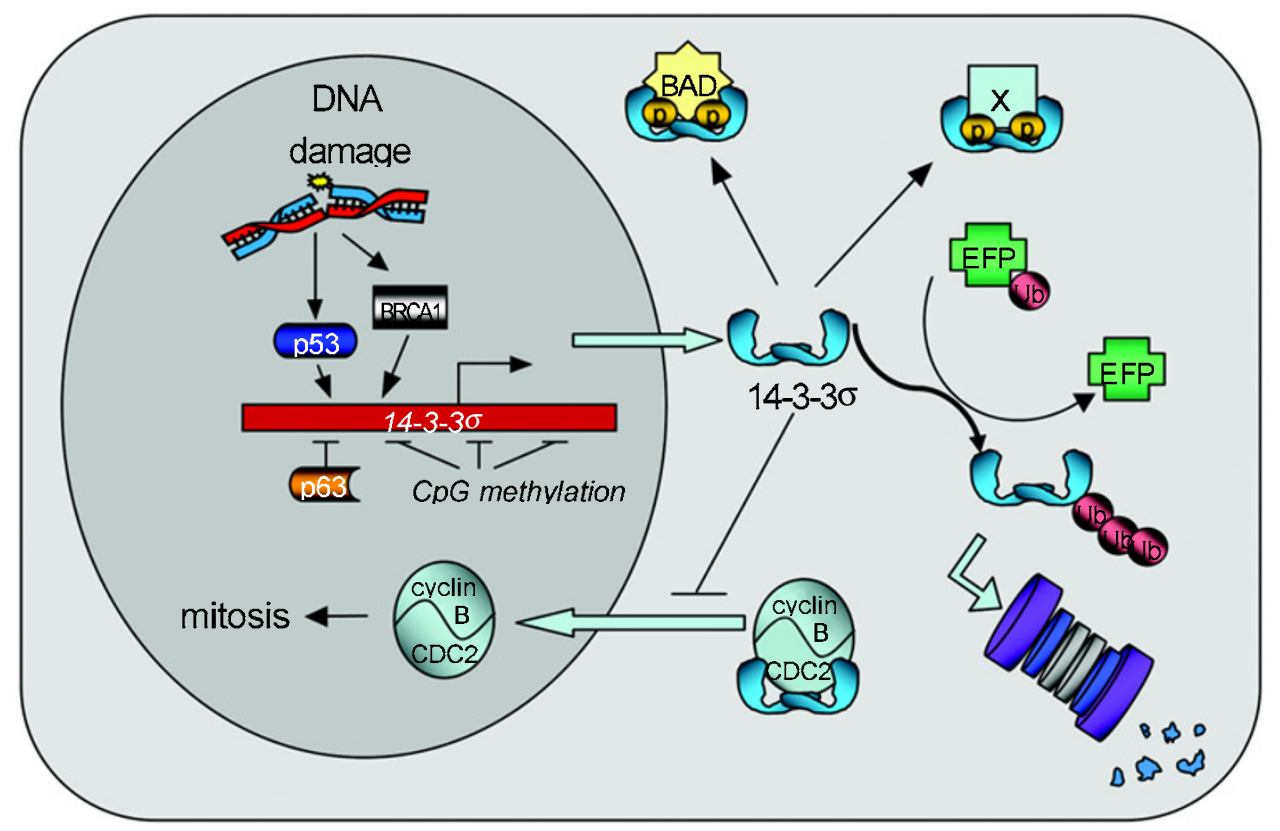

Fig. 4 Regulation and function of 14-3-3 $\sigma$. After DNA damage p53 binds to the promoter and induces transcription of the 14-3-3 $\sigma$ gene. BRCA1 acts as a co-activator in the induction of $14-3-3 \sigma$ transcription by $\mathrm{p} 53$. In the cytoplasm 14-3-3 $\sigma$ forms homodimers and binds to a variety of ligands phosphorylated at the serine/threonine residues in a consensus binding motif. The nuclear translocation of cyclin $\mathrm{B} / \mathrm{CDC} 2$ complexes required for the initiation of mitosis is inhibited by 14-3-3 $\sigma$. The BH3-domain protein BAD phosphorylated by AKT associates with 14-3-3 $\sigma$ and loses its ability to antagonize the function of the anti-apoptotic BCL2-like proteins. A dominant negative form of p63 $(\Delta \mathrm{Np} 63 \alpha)$ represses $14-3-3 \sigma$ expression. CpG methylation mediates epigenetic silencing of $14-3-3 \sigma$ in neoplasia and in normal, non-epithelial cells. A RING-finger-dependent E3 ubiquitin (Ub) ligase (EFP) targets 14-3-3 $\sigma$ for proteasomal degradation. $\mathrm{X}=$ unknown binding partner.

ing of interaction domains and export or import sequences, prevention of degradation, modulation of enzymatic activity and transactivation, and by facilitation of protein modifications (reviewed in [30,60]).

\section{4-3-3 $\sigma$ in the DNA damage response}

$14-3-3 \sigma$ is the only $14-3-3$ isoform, which is induced after DNA damage (Fig. 4). Induction of 14-3-3 $\sigma$ mRNA by DNA damage was identified in a SAGE (serial analysis of gene expression; [61]) based screen for genes induced after $\gamma$-irradiation in colorectal cancer cells expressing wild type p53 [62]. In this study p53 was found to directly activate the transcription of $14-3-3 \sigma$ [62]. The tumor suppressor protein $\mathrm{p} 53$ is a nodal point in the network of DNA damage induced signaling pathways and mediates inhibition of cell proliferation, presumably to allow time for repair or to permanently arrest damaged cells [63]. The net effect of p53 activation, which is typically proliferation arrest or apoptosis, is determined by the subset of transcriptional targets activated in a certain cell type and signaling context. Together with $p 21^{\text {WAFI }}, 14-3-3 \sigma$ belongs to a subset of p53 targets which mediate cycle arrest, whereas other $\mathrm{p} 53$ target genes mediate programmed cell death. $\Delta \mathrm{Np} 63 \alpha$, an isoform of the $\mathrm{p} 53$ homolog p63, which lacks a transactivation domain, was shown to bind to the p53responsive element in the $14-3-3 \sigma$ promoter, but, in contrast to 553 , represses transcription of 14-3-3 $\sigma$. Interestingly, 14-3-3 $\sigma$ was shown to participate in the nuclear export of $\Delta \mathrm{Np} 63 \alpha$ protein and thereby promote its proteosomal degradation after DNA damage in squamous cell carcinoma of the head and neck [64]. BRCA1 was shown to affect $\mathrm{G}_{2} / \mathrm{M}$ progression by inducing expression of $14-3-3 \sigma[65]$.

The ectopic expression of 14-3-3 $\sigma$ in colorectal cancer cells and primary prostate epithelial cells leads to the initiation of a $\mathrm{G}_{2}$ arrest [62]. A similar effect was observed in breast carcinoma cell line in which $14-3-3 \sigma$ is epigenetically silenced [32]. Disruption of the 14-3-3 $\sigma$ gene by homologous recombination in colon cancer cells results in impaired $\mathrm{G}_{2} / \mathrm{M}$ checkpoint after DNA damage: $\gamma$-irradiated 14-3-3 $\sigma$ knockout cells are unable to maintain a $\mathrm{G}_{2}$ arrest and eventually undergo mitotic catastrophe $[66,67]$. Moreover, 14-3-3 $\sigma$-deficient cells show increased genomic instability, characterized by loss of telomeric repeat sequences, chromosome end-to-end fusions and non- 
reciprocal translocations [68]. Breast cancer cells with hypermethylation of 14-3-3 $\sigma$ display increased genomic instability [32]. Furthermore, RNAi-mediated down-regulation of 14-3-3 $\sigma$ protein expression in prostate carcinoma cells was shown to compromise the stability of a DNA damage induced $\mathrm{G}_{2}$ arrest [33] and promote polyploidisation (Lodygin et al, unpublished results). Taken together, these results strongly argue for an important role of 14-3$3 \sigma$ in the maintenance of genomic integrity after DNA damage and suggest that the epigenetic silencing of this gene in cancer cells may contribute to the chromosomal instability.

\section{4-3-3 $\sigma$ functions in keratinocytes}

Among epithelial tissues, the epidermis is characterized by the highest level of 14-3-3 $\sigma$ expression. Keratinocytes which exit from the stem cell compartment and differentiate show an increase in 14-3-3 $\sigma$ expression [69], suggesting that 14-3-3 $\sigma$ may be linked to terminal differentiation of epithelial cells. In addition, $14-3-3 \sigma$ was implicated in senescence of primary human keratinocytes cultured in vitro. Experimental inactivation of $14-3-3 \sigma$ in primary keratinocytes by an anti-sense approach allows keratinocytes to evade senescence and become immortal without additional genetic alterations [70]. How the loss of 14-3-3 $\sigma$ contributes to immortalization is not clear. However, it is possible that the epigenetic silencing of $14-3-3 \sigma$ in keratinocytes may contribute to $\mathrm{BCC}$ formation by inactivation of senescence pathways which normally limit the proliferative capacity.

One unexpected function of 14-3-3 $\sigma$ in keratinocytes was recently described by Ghahary and colleagues: differentiated keratinocytes secrete 14-3-3 $\sigma$ and thereby induce expression of collagenase/MMP-1 (matrix metalloproteinase 1) in co-cultured dermal fibroblasts $[71,72]$ (see comment: [73]). Supporting this finding the addition of the recombinant 14-3-3 $\sigma$ protein to fibroblast cultures had also induced MMP-1 expression. MMP-1 is a key enzyme for the degradation of collagen, which is the main component of the extracellular matrix (ECM) produced largely by fibroblasts. Excessive accumulation of ECM proteins during wound healing process can lead to the fibrosis and formation of hypertrophic posttraumatic scars. The delay in epithelialization, due to either infection or severity of injury, increases the frequency of developing fibrotic conditions. Therefore, $14-3-3 \sigma$ is a candidate factor which could mediate the signaling from keratinocytes to the fibroblasts to switch from collagen accumulation to maturation and remodeling during wound healing. Moreover, the keratinocytes co-cultured with dermal fibroblasts seem to express a greater level of 14-3-3 $\sigma$ mRNA, suggesting the existence of a stroma-derived factor which regulates $14-3-3 \sigma$ expression.

\section{4-3-3 $\sigma$ protein ligands}

Candidate approaches led to the identification of several important cellular targets of 14-3-3 $\sigma$. For example, binding of $14-3-3 \sigma$ to $\mathrm{CDC} 2 /$ cyclin B1 complex provides a mechanistic explanation for the effect of induced 14-3-3 $\sigma$ expression observed after DNA damage. Cytpoplasmic 14-3-3 $\sigma$ prevents nuclear localization of the CDC2/cyclin $\mathrm{B}$ complex, which is required for progression through mitosis [66] (Fig. 4).

In addition, 14-3-3 $\sigma$ was shown to bind to $G_{1}$-specific CDKs (cyclin dependent kinases), such as CDK2 and CDK4 [74]. Therefore, 14-3-3 $\sigma$ may contribute to the $G_{1}$ arrest in epithelial cells. $14-3-3 \sigma$ contains a putative CDKinteraction motif found in other CDK-binding proteins [74]. Presumably the interaction between $14-3-3 \sigma$ and CDKs is not dependent on ligand phosphorylation, and might therefore depend on the availability of the 14-3-3 $\sigma$ protein, which is regulated on the transcriptional and post-translational level.

14-3-3 proteins are known to antagonize programmed cell death. The molecular basis for this effect may by the interaction with the $\mathrm{BH} 3$-family protein $\mathrm{BAD}$, which is sequentially phosphorylated by protein kinase $\mathrm{B}$ (AKT) and protein kinase A(PKA) in response to survival stimuli. Binding of the phosphorylated BAD protein to 14-3-3 releases the anti-apoptotic BCL2 protein from the BAD/BCL2 heterodimeric complex, resulting in the inhibition of apoptosis [75]. 14-3-3 $\sigma$ was shown to interact with BAD [76]. The pro-apoptotic $\mathrm{BH} 3$ protein $\mathrm{BAX}$ also associates with $14-3-3 \sigma$ [77]. Loss of this interaction may contribute to the enhanced sensitivity of $14-3-3 \sigma$-deficient HCT116 cells to DNA damage.

The levels of $14-3-3 \sigma$ proteins seem to be tightly controlled by ubiquitin-mediated proteasomal degradation. Ubiquitylation of $14-3-3 \sigma$ by the EFP protein, which is a

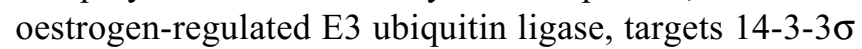
for proteasomal degradation [78]. The functional significance of this regulation was illustrated by experiments in animal models, in which EFP status modulated the growth

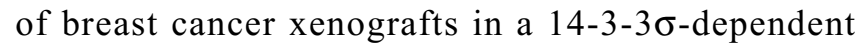
manner [79].

Recently, we applied a targeted proteomics approach to identify novel binding partners of 14-3-3 $\sigma$ [79]. Among 117 candidates identified by tandem affinity purification and subsequent mass-spectrometry-based MudPIT (multidimensional protein identification technology) analysis were 14 previously characterized and 103 new 14-3-3 $\sigma$ interacting proteins. The known function of the identified $14-3-3 \sigma$ interacting proteins indicates that $14-3-3 \sigma$ is involved in the regulation of cytoskeletal dynamics, polarity, 
adhesion, mitogenic signaling and motility in addition to its previously identified inhibitory effect on cell cycle progression.

It is a conundrum how the induction or loss of $14-3-3 \sigma$ has profound effects in the presence of large amounts of endogenous 14-3-3 proteins expressed by the 6 other 143-3 isoforms. Recently, we solved the crystal structure of the un-liganded 14-3-3 $\sigma$ dimer (PDB entry 1YZ5) and compared this structure to the known structure of 14-3$3 \tau$ and $\zeta$ (published in this issue; see reference [80]). Thereby, we could identify putative determinants of 14-3$3 \sigma$ ligand binding and dimerization [80]. High structural conservation was identified in the phosphopeptide binding cleft among the 14-3-3 isoforms $\sigma, \tau$ and $\zeta$. A region adjacent to this posphopeptide binding pocket and a nonconserved loop (amino acids 203-215) were identified as potential ligand binding specificity regions [80]. Furthermore, non-conserved residues at the dimerization interface were identified the 14-3-3 $\sigma$ structure [80]. These residues may determine the dimerization specificity. Such selective dimerization specificity may exist as we only detected 14-3-3 $\sigma$ homodimers and heterodimers with endogenous $14-3-3 \gamma$ protein in a targeted proteomics analysis of $14-3-3 \sigma$ [79].

\section{CONCLUDING REMARKS}

Down-regulation of 14-3-3 $\sigma$ expression is commonly found in different types of carcinoma, including early stages of tumor development. This indicates that the function of 14-3-3 $\sigma$ may contribute to the prevention of malignant transformation of epithelial cells. The known functional properties of 14-3-3 $\sigma$ suggest, that epigenetic silencing of 14-3-3 $\sigma$ in cancer cells results in defective cell-cycle control after DNA damage and promotes genomic instability. Recently identified, novel 14-3-3 $\sigma$-interacting proteins implicate $14-3-3 \sigma$ in the regulation of diverse cellular processes (migration, adhesion, polarity, MAPK and wnt signaling). It will be interesting to determine to which extent $14-3-3 \sigma$ loss by $\mathrm{CpG}$ methylation or p53 mutation contributes to deregulation of these processes in cancer cells. In the future, the frequent cancer-specific $\mathrm{CpG}$ methylation of 14-3-3 $\sigma$ may be used as a diagnostic tool in combination with recently developed techniques that allow the analysis of the methylation status in disseminated cancer cells found in body fluids (for a review, see [81]).

\section{ACKNOWLEDGEMENTS}

Work in Heiko Hermeking's lab is supported by the MaxPlanck-Society and the Dr- Mildred Scheel-Stiftung/
Deutsche Krebshilfe.

\section{REFERENCES}

1 Kinzler KW, Vogelstein B. Cancer-susceptibility genes. Gatekeepers and caretakers. Nature 1997; 386:761-3.

2 Li E. Chromatin modification and epigenetic reprogramming in mammalian development. Nat Rev Genet 2002; 3:662-73.

3 Bird A. DNA methylation patterns and epigenetic memory. Genes Dev 2002; 16:6-21.

4 Jaenisch R, Bird A. Epigenetic regulation of gene expression: how the genome integrates intrinsic and environmental signals. Nat Genet 2003; 33 Suppl:245-54.

5 Takai D, Jones PA. Comprehensive analysis of CpG islands in human chromosomes 21 and 22. Proc Natl Acad Sci U S A 2002; 99:3740-5.

6 Feinberg AP, Vogelstein B. Hypomethylation distinguishes genes of some human cancers from their normal counterparts. Nature 1983; 301:89-92.

7 Gaudet F, Hodgson JG, Eden A, et al. Induction of tumors in mice by genomic hypomethylation. Science $2003 ; \mathbf{3 0 0}: 489-92$.

8 Eden A, Gaudet F, Waghmare A, Jaenisch R. Chromosomal instability and tumors promoted by DNA hypomethylation. Science 2003; 300:455.

9 Robertson KD, Keyomarsi K, Gonzales FA, Velicescu M, Jones PA. Differential mRNA expression of the human DNA methyltransferases (DNMTs) $1,3 \mathrm{a}$ and $3 \mathrm{~b}$ during the $\mathrm{G}_{0} / \mathrm{G}_{1}$ to $\mathrm{S}$ phase transition in normal and tumor cells. Nucleic Acids Res 2000; 28 : 2108-13.

10 De Marzo AM, Marchi VL, Yang ES, et al. Abnormal regulation of DNA methyltransferase expression during colorectal carcinogenesis. Cancer Res 1999; 59:3855-60.

11 Bakin AV, Curran T. Role of DNA 5-methylcytosine transferase in cell transformation by fos. Science 1999; 283:387-90.

12 Tamaru H and Selker EU. A histone H3 methyltransferase controls DNA methylation in Neurospora crassa. Nature 2001; 414: 277-83.

13 Jackson JP, Lindroth AM, Cao X, Jacobsen SE. Control of CpNpG DNA methylation by the KRYPTONITE histone H3 methyltransferase. Nature 2002; 416:556-60.

14 Lehnertz B, Ueda Y, Derijck AA, et al. Suv39h-mediated histone H3 lysine 9 methylation directs DNA methylation to major satellite repeats at pericentric heterochromatin. Curr Biol 2003; 13: 1192-200.

15 Bachman KE, Park BH, Rhee I, et al. Histone modifications and silencing prior to DNA methylation of a tumor suppressor gene. Cancer Cell 2003; 3:89-95.

16 Matzke M, Matzke AJ, Kooter JM. RNA: guiding gene silencing. Science 2001; 293:1080-3.

17 Bender J. A vicious cycle: RNA silencing and DNA methylation in plants. Cell 2001; 106:129-32.

18 Kawasaki H, Taira K. Induction of DNA methylation and gene silencing by short interfering RNAs in human cells. Nature 2004; 431:211-7.

19 Morris KV, Chan SW, Jacobsen SE, Looney DJ. Small interfering RNA-induced transcriptional gene silencing in human cells. Science 2004; 305:1289-1292.

20 Brenner C, Deplus R, Didelot C, et al. Myc represses transcription through recruitment of DNA methyltransferase corepressor. Embo J 2005; 24:336-46. 
21 Jones PA, Baylin SB. The fundamental role of epigenetic events in cancer. Nat Rev Genet 2002; 3:415-28.

22 Herman JG, Civin CI, Issa JP, et al. Distinct patterns of inactivation of $\mathrm{p} 15^{\mathrm{INK} 4 \mathrm{~b}}$ and $\mathrm{p} 16^{\mathrm{INK} 4 \mathrm{a}}$ characterize the major types of hematological malignancies. Cancer Res 1997; 57:837-41.

23 Lin X, Asgari K, Putzi MJ, et al. Reversal of GSTP1 CpG island hypermethylation and reactivation of pi-class glutathione S-transferase (GSTP1) expression in human prostate cancer cells by treatment with procainamide. Cancer Res 2001; 61:8611-6.

24 Hopkins-Donaldson S, Ziegler A, Kurtz S, et al. Silencing of death receptor and caspase- 8 expression in small cell lung carcinoma cell lines and tumors by DNA methylation. Cell Death Differ 2003; 10:356-64.

25 Rhee I, Bachman KE, Park BH, et al. DNMT1 and DNMT3b cooperate to silence genes in human cancer cells. Nature 2002; 416:552-6.

26 Eads CA, Nickel AE, Laird PW. Complete genetic suppression of polyp formation and reduction of CpG-island hypermethylation in Apc(Min/+) Dnmt1-hypomorphic Mice. Cancer Res 2002; 62:1296-9.

27 Sansom OJ, Berger J, Bishop SM, et al. Deficiency of Mbd2 suppresses intestinal tumorigenesis. Nat Genet 2003; 34:145-7.

28 Paz MF, Fraga MF, Avila S, et al. A systematic profile of DNA methylation in human cancer cell lines. Cancer Res 2003; 63: 1114-21.

29 Suter CM, Martin DI, Ward RL. Germline epimutation of MLH1 in individuals with multiple cancers. Nat Genet 2004; 36:497501.

30 Hermeking H. The 14-3-3 cancer connection. Nat Rev Cancer 2003; 3:931-43.

31 Nacht M, Ferguson AT, Zhang W, et al. Combining serial analysis of gene expression and array technologies to identify genes differentially expressed in breast cancer. Cancer Res 1999; 59: 5464-70.

32 Ferguson AT, Evron E, Umbricht CB, et al. High frequency of hypermethylation at the 14-3-3 $\sigma$ locus leads to gene silencing in breast cancer. Proc Natl Acad Sci U S A 2000; 97:6049-54.

33 Lodygin D, Diebold J, Hermeking H. Prostate cancer is characterized by epigenetic silencing of $14-3-3 \sigma$ expression. Oncogene 2004; 23:9034-41.

34 Lodygin D, Epanchintsev A, Menssen A, Diebold J, Hermeking $H$. Functional epigenomics identifies genes frequently silenced in prostate cancer. Cancer Res 2005; in press.

35 Kaneuchi M, Sasaki M, Tanaka Y et al. Expression and methylation status of 14-3-3 $\sigma$ gene can characterize the different histological features of ovarian cancer. Biochem Biophys Res Commun 2004; 316:1156-62.

36 Mhawech P, Greloz V, Assaly M, Herrmann F. Immunohistochemical expression of $14-3-3 \sigma$ protein in human urological and gynecological tumors using a multi-tumor microarray analysis. Pathol Int 2005; 55:77-82.

37 Umbricht CB, Evron E, Gabrielson E, et al. Hypermethylation of $14-3-3 \sigma$ (stratifin) is an early event in breast cancer. Oncogene 2001; 20:3348-53.

38 Lodygin D, Yazdi AS, Sander CA, Herzinger T, Hermeking H. Analysis of 14-3-3 $\sigma$ expression in hyperproliferative skin diseases reveals selective loss associated with $\mathrm{CpG}$-methylation in basal cell carcinoma. Oncogene 2003; 22:5519-24.

39 Iwata N, Yamamoto H, Sasaki S, et al. Frequent hypermethylation of $\mathrm{CpG}$ islands and loss of expression of the $14-3-3 \sigma$ gene in human hepatocellular carcinoma. Oncogene 2000; 19:5298-302.

40 Tokugawa T, Sugihara H, Tani T, Hattori T. Modes of silencing of p16 in development of esophageal squamous cell carcinoma. Cancer Res 2002; 62:4938-44.

41 Ivanova T, Petrenko A, Gritsko T, et al. Methylation and silencing of the retinoic acid receptor- $\beta 2$ gene in cervical cancer. BMC Cancer 2002; 2:4.

$42 \mathrm{Li}$ Z, Meng ZH, Chandrasekaran R, et al. Biallelic inactivation of the thyroid hormone receptor $\beta 1$ gene in early stage breast cancer. Cancer Res 2002; 62:1939-43.

43 Moreira JM, Ohlsson G, Rank FE, Celis JE. Downregulation of the tumor suppressor protein $14-3-3 \sigma$ is a sporadic event in cancer of the breast. Mol Cell Proteomics 2005; 4:555-69.

44 Sano T, Shimooka H, Weixa P, et al. Immunohistochemical expression of 14-3-3 $\sigma$ protein in various histological subtypes of uterine cervical cancers. Pathol Int 2004; 54:743-50.

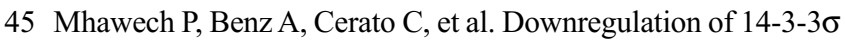
in ovary, prostate and endometrial carcinomas is associated with CpG island methylation. Mod Pathol 2005; 18:340-8.

46 Gasco M, Bell AK, Heath V, et al. Epigenetic inactivation of 14$3-3 \sigma$ in oral carcinoma: association with $\mathrm{p} 16^{\mathrm{INK} 4 \mathrm{a}}$ silencing and human papillomavirus negativity. Cancer Res 2002; 62:2072-6.

47 Bhatia K, Siraj AK, Hussain A, Bu R, Gutierrez MI. The tumor suppressor gene 14-3-3 $\sigma$ is commonly methylated in normal and malignant lymphoid cells. Cancer Epidemiol Biomarkers Prev 2003; 12:165-9.

48 Iacobuzio-Donahue CA, Maitra A, Olsen M, et al. Exploration of global gene expression patterns in pancreatic adenocarcinoma using cDNA microarrays. Am J Pathol 2003; 162:1151-62.

49 Sato N, Maitra A, Fukushima N, et al. Frequent hypomethylation of multiple genes overexpressed in pancreatic ductal adenocarcinoma. Cancer Res 2003; 63:4158-66.

50 Guweidhi A, Kleeff J, Giese N, et al. Enhanced expression of 14$3-3 \sigma$ in pancreatic cancer and its role in cell cycle regulation and apoptosis. Carcinogenesis 2004; 25:1575-85.

51 Simooka H, Oyama T, Sano T, Horiguchi J, Nakajima T. Immunohistochemical analysis of $14-3-3 \sigma$ and related proteins in hyperplastic and neoplastic breast lesions, with particular reference to early carcinogenesis. Pathol Int 2004; 54:595-602.

52 Suzuki $\mathrm{H}$, Itoh F, Toyota M, et al. Inactivation of the 14-3-3 $\sigma$ gene is associated with 5' CpG island hypermethylation in human cancers. Cancer Res 2000; 60:4353-57.

53 Lee S, Kim WH, Jung HY, Yang MH, Kang GH. Aberrant CpG island methylation of multiple genes in intrahepatic cholangiocarcinoma. Am J Pathol 2002; 161:1015-22.

54 Osada H, Tatematsu Y, Yatabe Y, et al. Frequent and histological type-specific inactivation of $14-3-3 \sigma$ in human lung cancers. Oncogene 2002; 21:2418-24.

55 Yatabe Y, Osada H, Tatematsu Y, Mitsudomi T, Takahashi T. Decreased expression of $14-3-3 \sigma$ in neuroendocrine tumors is independent of origin and malignant potential. Oncogene 2002; 21:8310-9.

56 Gasco M, Sullivan A, Repellin C, et al. Coincident inactivation of $14-3-3 \sigma$ and $p 16^{\text {INK4a }}$ is an early event in vulval squamous neoplasia. Oncogene 2002; 21:1876-81.

57 Akahira J, Sugihashi Y Suzuki T, et al. Decreased expression of $14-3-3 \sigma$ is associated with advanced disease in human epithelial ovarian cancer: its correlation with aberrant DNA methylation. Clin Cancer Res 2004; 10:2687-93.

58 Cheng L, Pan CX, Zhang JT, et al. Loss of $14-3-3 \sigma$ in prostate 


\section{4-3-3 $\sigma$ inactivation in cancer}

cancer and its precursors. Clin Cancer Res 2004; 10:3064-8.

59 Urano T, Takahashi S, Suzuki T, et al. 14-3-3 $\sigma$ is down-regulated in human prostate cancer. Biochem Biophys Res Commun 2004; 319:795-800.

60 Mhawech P. 14-3-3 proteins - an update. Cell Res 2005; 15: 228-36

61 Hermeking H. Serial analysis of gene expression and cancer. Curr Opin Oncol 2003; 15:44-9.

62 Hermeking $\mathrm{H}$, Lengauer C, Polyak K, et al. $14-3-3 \sigma$ is a p53regulated inhibitor of $\mathrm{G}_{2} / \mathrm{M}$ progression. Mol Cell 1997; 1:3-11.

63 Vogelstein, B, Lane D, Levine AJ, Surfing the p53 network. Nature 2000; 408:307-10.

64 Fomenkov A, Zangen R, Huang YP, et al. RACK1 and stratifin target $\Delta \mathrm{Np} 63 \alpha$ for a proteasome degradation in head and neck squamous cell carcinoma cells upon DNA damage. Cell Cycle 2004; 3:1285-95.

65 Aprelikova O, Pace AJ, Fang B, Koller BH, Liu ET. BRCA1 is a selective co-activator of 14-3-3 $\sigma$ gene transcription in mouse embryonic stem cells. J Biol Chem 2001; 276:25647-50.

66 Chan TA, Hermeking H, Lengauer C, Kinzler KW, Vogelstein B. $14-3-3 \sigma$ is required to prevent mitotic catastrophe after DNA damage. Nature 1999; 401:616-20.

67 Chan TA, Hwang PM, Hermeking, H, Kinzler KW, Vogelstein B. Cooperative effects of genes controlling the $\mathrm{G}_{2} / \mathrm{M}$ checkpoint. Genes Dev 2000; 14:1584-8.

68 Dhar S, Squire JA, Hande MP, Wellinger RJ, Pandita TK. Inactivation of 14-3-3 $\sigma$ influences telomere behavior and ionizing radiation-induced chromosomal instability. Mol Cell Biol 2000; 20:7764-72.

69 Pellegrini G, Dellambra E, Golisano O, et al. p63 identifies keratinocyte stem cells. Proc Natl Acad Sci U S A 2001; 98:3156-61.

70 Dellambra E, Golisano O, Bondanza S, et al. Downregulation of 14-3-3 $\sigma$ prevents clonal evolution and leads to immortalization of primary human keratinocytes. J Cell Biol 2000; 149:111730.
71 Ghahary A, Karimi-Busheri F, Marcoux Y, et al. Keratinocytereleasable stratifin functions as a potent collagenase-stimulating factor in fibroblasts. J Invest Dermatol 2004; 122:1188-97.

72 Ghahary A, Marcoux Y, Karimi-Busheri F, et al. Differentiated keratinocyte-releasable stratifin (14-3-3 $\sigma$ ) stimulates MMP-1 expression in dermal fibroblasts. J Invest Dermatol 2005; 124: 170-177.

73 Hermeking H. Extracellular 14-3-3 $\sigma$ protein: a potential mediator of epithelial-mesenchymal interactions. J Invest Dermatol 2005; 124:ix-x.

74 Laronga C, Yang HY, Neal C, Lee MH. Association of the cyclindependent kinases and 14-3-3 $\sigma$ negatively regulates cell cycle progression. J Biol Chem 2000; 275:23106-12.

75 Datta SR, Katsov A, Hu L, et al. 14-3-3 proteins and survival kinases cooperate to inactivate $\mathrm{BAD}$ by $\mathrm{BH} 3$ domain phosphorylation. Mol Cell 2000; 6:41-51.

76 Subramanian RR, Masters SC, Zhang H, Fu H. Functional conservation of 14-3-3 isoforms in inhibiting bad-induced apoptosis. Exp Cell Res 2001; 271:142-51.

77 Samuel T, Weber HO, Rauch $\mathrm{P}$, et al. The $\mathrm{G}_{2} / \mathrm{M}$ regulator 14-3$3 \sigma$ prevents apoptosis through sequestration of Bax. J Biol Chem 2001; 276:45201-6.

78 Urano T, Saito T, Tsukui T, et al. Efp targets 14-3-3 $\sigma$ for proteolysis and promotes breast tumour growth. Nature 2002; 417: 871-5.

79 Benzinger A, Muster N, Koch HB, Yates JR $3^{\text {rd }}$, Hermeking H. Targeted proteomic analysis of 14-3-3 $\sigma$, a p53 effector commonly silenced in cancer. Mol Cell Proteomics 2005. March 18 epub ahead of print.

80 Benzinger A, Popowicz GM, Joy JK, et al. The crystal structure of the non-liganded 14-3-3 $\sigma$ protein: insights into determinants of isoform specific ligand binding and dimerization. Cell Res $2005 ; \mathbf{1 5}: 219-27$

81 Laird PW. The power and the promise of DNA methylation markers. Nat Rev Cancer 2003; 3:253-66. 